The EDTA titration of gallium in copperniobium-gallium alloys. Shurô Takeyama, Masahiko SASE and Yuetsu DANzaki (The Research Institute for Iron, Steel and Other Metals, Tohoku University, 2-1-1, Katahira, Sendai-shi, Miyagi)

The complexometric method for gallium in $\mathrm{Cu}$ $(20 \sim 40) \% \mathrm{Nb}-(1 \sim 6) \% \mathrm{Ga}$ alloys was developed. Sample was dissolved in nitric acid and hydrofluoric acid. After adding sulfuric acid, the solution was heated, evaporated to $\mathrm{SO}_{3}$ fume, and then cooled. The salts were dissolved in water, copper and niobium were precipitated by bromine water and sodium hydroxide. A small amount of dissolved niobium in the filtrate was masked by the mixture of $10 \mathrm{ml}$ of $47 \%$ hydrofluoric acid and $200 \mathrm{ml}$ of saturated boric acid solution. After adjusting $\mathrm{pH}$ at $3 \sim 3.5$ by sodium acetate, gallium was titrated with EDTA at $>90^{\circ} \mathrm{C}$ using $\mathrm{Cu}-\mathrm{PAN}$ as indicator. In the presence of niobium $(<1 \mathrm{mg})$, copper and gallium was determined by back titration of excess EDTA with zinc (II) solution using Xylenol Orange involving the masking of copper with thiourea.

(Received Feb. 12, 1980)

\section{Keywords}

Copper-niobium-gallium alloy

EDTA titration

Gallium

\title{
ガスクロマトグラフィー-質量分析法による窒素中の 二酸化岩素の定量分析法
}

\author{
野副尚一*®，山崎善武**，富田 弘，染野和雄* \\ (1980 年 1 月 7 日受理)
}

\begin{abstract}
窒素中の微量不純物成分を，低濃度標準ガスを用いることなく赤外分光 (IR) 法によって定量分析す る方法については既に報告がある。本研究では，IR 法によっては行い難い窒素中の二酸化炭素の高精 度の定量分析をがスクロマトグラフー質量分析 (GC-MS) 法により行ら方法を示した.

従来，GG-MS 法により高精度の定量分析を行うことは困難であると考えられてきた。この要因に ついて検副を加え，問題点について解決策を与光た.

質量分析計の出力の不安定性は参照ガスと試料ガスを 6 分間以内に測定して，これらの測定によるピ ーク面積の比較を行うことにより避けるととができる.

定量分析の目的のためには二次電子增倍管よりもフォラデーカップのほうが優れている.

空素の質量分析計への影響は，窒素がガスクロマトグラフから質量分析計のイオン源に溶出している ときにリペラー電極に負の電位を与えることにより避けた。

本研究で示した方法を用いることにより，GC-MS 法を用いて，窒素中の二酸化炭素の濃度が 100 $\%$ から ppm 程度のものを，低濃度標準ガスを用いることなく高精度で定量分析することが可能とな った。この片は，他の無機ガスについても適用することがてきる。
\end{abstract}

\section{1 緒}

IR 法により低濃度標準ガスを用いることなく，窒素 中の一酸化炭萦, メタン，プロパン及び一酸化空素を高 精度で定量分析する方法については既に報告がある11. 本研究は, IR 法によっては行い難い窒素中の二酸化炭

* 化学技術研究所: 茨城県筑波郡谷田部町東 1-1 ** 元化学品検查協会 : 東京都墨田区東向島 4-1-1
素を GC-MS 法により，しかも低濃度標準ガスを用い ることなく，高精度で定量分析する力法を開発すること を目的とした。

気体試料中の微量成分の分析を GC-MS 法により行 うことは，GC-MS 法が高感度でしかも高選択的である ことから広く行われている. しかし，これらの研究は主 に検出限界について検討を加えたものであり2)3)， GGMS 法により定量分析を行ら際の定量精度あるいは確度 
について検吋を加えた例はない.

\section{2 笑験及び考察}

\section{$2 \cdot 1$ 装}

装置の概要を Fig. 1 に示す. GG-MS 装置としては, 残留ガスによる質量分析計のパックグラウンドのピーク を低く抑え，しかもイオン源にできるだけ大量の試料を 送り込えで検出感度を向上させるために，大排気速度の ポンプでイオン源を高真空まで排気できるものであるこ とが望ましい.しかも，質量分析計としては低質量数の イオンに対して高い透過率を持つ四重極質量分析計（マ スフィルター）が適当である.この条件を満たすものと して, 本研究では日電バリアン社製 TE-600 型 GGMS 装置を改造して使用した。

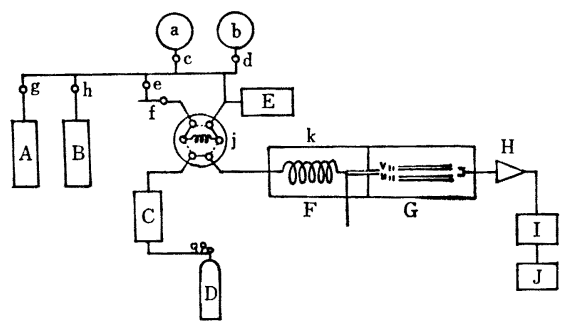

Fig. 1 Schematic diagram of the system A : Sample gas; B : Reference gas; G : Flow con-
troller; D: Helium gas; E : Capacitance manometer;
F : Gas chromatograph; G : Q-mass spectrometer; H :
Preamplifier; I : V-F converter; J : Minicomputer;
a, b: Gas bulbs; c $\sim$ h : 2 way valves; j: 6 way
valve; k : Splitter

ヘリウムキャリヤーの流量は流量コントローラー (Ueshima-Brooks 社製) を用いて一定に保った.

GC-MS の出力電流はピュアンメーター (Keithley 社 モデル 417) で増幅した後， V-F 变換してからミニ= ンピューター（Tracor-Northern 社モデル TN-11) を 用いてデータの收集及び解析を行った.

気体試料導入装置は金属べローバルブ，パイレックス ガラス, SUS 304 ステンレスを材料として組み立て, 水銀拡散ポンプ，液体空素トラップ，及び油回転ポンプ の組み合わせにより，油による污染のない 10-6 Torr の真空度まで排父することができる.この気体試料導入 装置には $5 \times 10^{-6}$ Torr $\mathrm{ml} \mathrm{min-1}$ 以上の漏れがないこ とを確認した.

父体試料の圧力測定はキャパシタンスマノメーター (MKS Instruments 社バラトロン，モデル 170) により 上0.15\%の精度で行った.

\section{2 ガスクロマトグラフの測定条件の設定}

本研究で用いた GC-MS は，窒素に対して 28001 $\mathbf{s}^{-1}$ の排気速度を持つ油拡散ポンプで排気しているので，

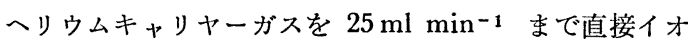

ン源に導入することがでさる.しかしこのような直接導 入法をとると，広範囲にわたってキャリヤーガスの流量 を変えられないため, 流量をガスクロートグラフの最適 条件に設定することが難しいたけでなく， GC のサンプ ルループに 1 弎生以下の試料を導入すると, GC の条件 によってはとの影響が GC-MS の出力のベースライン に現れやすい。

GC の出口と質量分析計の入口の間に内径 $6 \mathrm{~mm} \phi$ の ステンレス製T字管 (Swagelock 社 TEE) を入れてへ リウムキャリヤーガスの一部を大気側に流出させた． T 子管に流入するキャリヤーガ大の流量を質量流量コント ローラーで一分にし，T字管の大気側への流量を石けん 膜流量計で測定した. 測定結果を Fig. 2 に示す.この T字管を用いたとき，GCを流れるへリウムキャリヤー ガスの流量を㤝い範囲にわたって変えても，質量分析叶 に流入するキャリヤーガスの流量は一是であり，この場

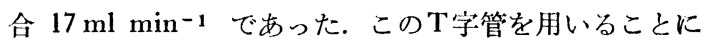
より，直接導入法の場合でも㕕い流量範囲にわたって， 質量分析計の測定条件とは独立に, キャリヤーガスの流 量を変えることができる.

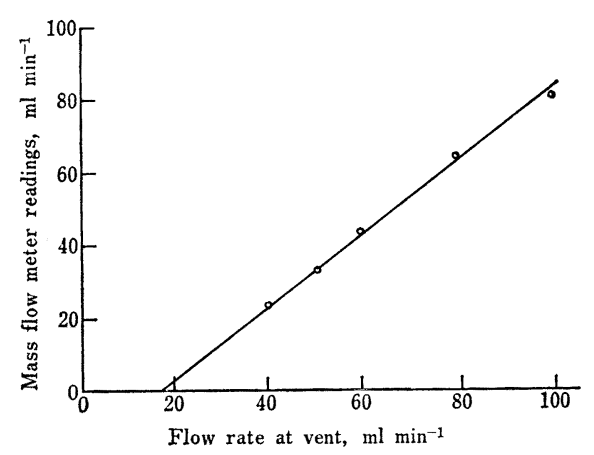

Fig. 2 Efficiency of the splitter As the gradient of the straight line is 1 , the flow rate
to the mass spectrometer is constant and independent
of the flow rate through the gas chromatograph. The
How rate to the mass spectrometer is determined to
be $17 \mathrm{ml} \mathrm{min-1}$ from the point of intersection of the
line and the abscissa.

GC の充てん剂としては堂素と二酸化炭素の分離度及 び熱的安定性を考慮してシリカゲルを用いた4).

\section{3 マスフィルターの安定性についての検討}

検量線法により定量分析を行うためには作成した検量 線が長時間にわたって不変でなければならない，検量線 法により定量分析を行えるか否かを検討するために，マ 
スフィルターの長時間安定性を調べた.なお，マスフィ ルターの出力のピークの高さはイオン源温度に依存する ので，すべての実験はフィラメントを点火後数時間以上 経過した後，イォン源に取り付けた熱電対によりイオン 源温度が一定となったことを確かめてから行った。

表示値 $1830 \mathrm{ppm}$ のボンべ詰め混合ガ火により，一定 濃度の二酸化炭素の定常流をつくり，これをオートサン テ゚シーで 6 分ごとに繰り返し測定して二酸化炭素の $m / e$ =44のピークの高さの繰り返し再現性を調べた。こ のよらにして調べた再現性の測定結果を Table 1 にホ す. 時間 $t_{0}$ と $t_{1}$ との時間間隔を $\Delta t$ とすると, その 間にマスフィルターの状態が不変であれば $t_{0}$ 及び $t_{1}$ に拈けるピークの高さの此は 1 となるはずである，実際 には $\Delta t$ が大きくなるに従って，つまり測定の間隔が主 くなるに従い，この比は1よりしだいに小さくなる。こ れは $m / e=44$ のピーク高さが時間とともに減少してゆ く傾问のあることを示す，十分注意して測定を行って も，マンフィルターの長時間安定性は，検量線法により 定量分析を行らには不十分であることが分かる。しかし 短時間のらちであれば (この装置の場合 6 分間以内), ーマンフィターの状態は一冦であるとみなすことがでさ

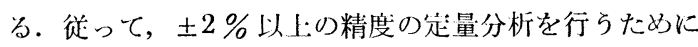
は，後に述べるように，末知濃度試料と参照試料の测足 を6 分以内に連続して行おなければならない。

Table 1 Reproducibility of the peak heights $(m / e=44)$ in gas chromatographymass spectrometry

\begin{tabular}{lccccc}
\hline$\Delta t$ (min) & 6 & 12 & 18 & 30 & 60 \\
Correlation factor & 0.998 & 0.996 & 0.995 & 0.991 & 0.976 \\
Number of data points & 24 & 23 & 22 & 20 & 15 \\
$v(\%)$ & 0.72 & 0.12 & 1.34 & 2.09 & 2.94 \\
\hline
\end{tabular}

$\Delta t \equiv t_{1}-t_{0}$ (an interval between successive measurements) correlation factor $\equiv$ (peak height at $\left.t-t_{1}\right) /\left(\right.$ peak height at $\left.t-t_{0}\right)$

窒素中の二酸化炭素の分析を行ら際には，どのような 允てん剤を用いても二酸化炭素がイオン源に流入する前 に大量の窒素がイオン源に流入することを避けることは でさない。酸化炭素と共存する窒少の影響を調べるた めに, 20 Torr の二酸化炭素を 740 Torr の窒冢に混合 した場合としない場合について，GC-MS の出力である $m / e=44$ のピークの面積強度の比をとった.

窒素がイオン源に流入してから二酸化炭素が流入すを までの時間間隔を 2 分間としたとき，この比は 0.978 \pm 0.004 となった. 䛊差を考慮しても 1 とみなすことは できない（窒素が共存しないときには，Table 1 から分
かるよらに，この比は 0.998 である). 窒素がイオン 源に流入してから二酸化炭素が流入するまで十分な時 間差があるので，窒素はイオン源から排気されてしま い, 窒素はイオン源に残留していないと思われる. 従っ て，この原因はイオン源で大量に生成した窒素イオン $\left(\mathrm{N}_{2}{ }^{+}\right)$がQポールの入口に衝突して電荷を失い, 入口 付近に付着した污れい影響でその部分を局部的に帯電さ せ，ースフィルターの測定条件が変化するためであると 思われる。この問題を避けるためには, 窒素がイオン源 に流入しないよらに，GC の出口で窒素をあらかじめカ ットしてもよいのであるが，本研究では大量に生成する 䆓素イオンがQポールに到着しないよらに，窒素がイオ ン源に流入している間だけ，ミニニンピューターからの 指示で, リペラー電極の電位を $-9 \mathrm{~V}$ 程度の電位とし た.このようにして前と同様に測定を行ったとこる，面 積強度の比は $1.009 \pm 0.008$ となり，注注誤差の範囲で 1となっている.このよらな测定法をとることにより大 量に存在する空素の影響を除くことができたので，足量 分析にはすべてこの力法を用いた.

\section{4 マスフィルターのダイナミックレンジの検討}

検量線法によることなく尘量分析を行らためには, GC-MS の感度（ここでは GG-MS の出力のピークの 面積強度をサンプルループ中の二酸化炭素の分生で除し た值を感度とする）が広い濃度範囲にわたって一走でな ければならない。これを確かめるために，サンプルルー プ中の二酸化炭素の 分圧を㕕範用に变えて GG-MS の 感度を調べた. マンフィルターの検出器として, 二次電 子増倍管（浜松テレビ R4R4）を用いたとさには Fig. 3 に示すように感度は左力依存性を示した，娭出器として フッシデーカップを用いたとさには，Fig. 4 に示すよ うに二酸化炭素の分生が一定の值より低い場合は感度は 一定となった。従って，検量線法によらずに高精度で足 量分析を行う場合，少なくも本研究で用いた装置の場 合，二次電子増倍管を用いることはでさない。

\section{5 定量分析法及び定量分析可能な濃度籍囲の検討}

サンプルループ中での 末知濃度試料の 全圧を $P_{1}$, 参 照試料（この場合は純粋な二酸化炭素）の全坧を $P_{2}$, それどれの試料を測定したときの GC-MS の二酸化炭 素に対する出力の面積強度を $S_{1}, S_{2}$ とすると, 未知濃 度試料中の二酸化炭素の分圧 $P_{0}$ は GG-MS の感度が 一定でしかも未知濃度試料の測定と参照試料の測定を所 定の時間（この場合，6分間）に行えば，次式で与えら れる。 


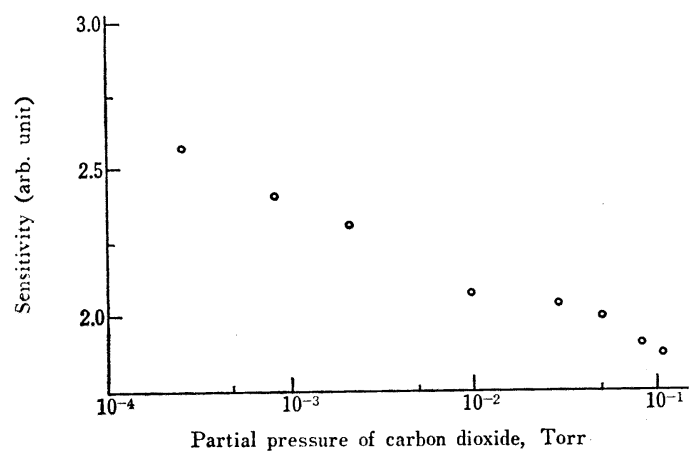

Fig. 3 The pressure dependence of the sensitivity determined by using a secondary electron multiplier as a detector of the mass spectrometer

Measuring condition- $\mathrm{High}$ voltage of SEM $: 2 \mathrm{kV}$, emission current : $100 \mu \mathrm{A}$, electron voltage : $16 \mathrm{eV}$; The sensitivity depends on the partial pressure of rarbon dioxide, when a SEM is used as a detector of the mass spectrometer.

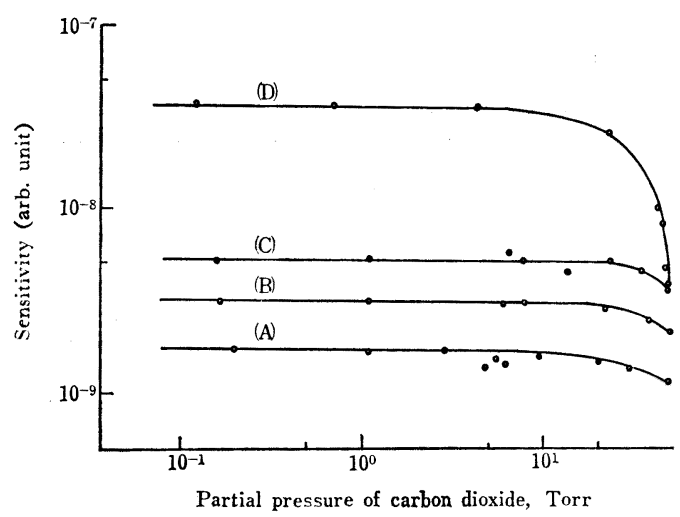

Fig. 4 The pressure dependence of the sensitivity determined by using a Faraday cup as a detector of the mass spectrometer

Measuring condition-(A) Emission current $\left(I_{\mathrm{k}}\right)$ : $1 \mu \mathrm{A}$, electron voltage $\left(E_{\mathrm{k}}\right): 16 \mathrm{eV}$, (B) $I_{\mathrm{k}}: 1 \mu \mathrm{A}$, $E_{\mathrm{k}}: 70 \mathrm{eV},\left(\right.$ C) $I_{\mathrm{k}}: 10 \mu \mathrm{A}, E_{\mathrm{k}}: 70 \mathrm{eV}$, (D) $I_{\mathrm{k}}: 100$ $\mu \mathrm{A}, E_{\mathrm{k}}: 70 \mathrm{eV}$; The sensitivity does not depend on the partial pressure of carbon dioxide so long as the partial pressure of carbun dioxide is not too high, when a Faraday cup is used as a detector of the mass spectrometer.

$$
P_{0}=P_{2} \cdot S_{1} / S_{2}
$$

従って, 未知濃度試料中の二酸化炭素の濃度 $C$ は次式 で決定される。

$$
C=P_{0} / P_{1}=\left(P_{2} / P_{1}\right) \times\left(S_{1} / S_{2}\right)
$$

定量分析可能な濃度範囲は，十分な精度で全圧を测定 できる範囲，十分な精度で面積強度を測定できる範囲， 及び GC-MS の感度が一定である範用によって決定さ れる.

サンプルループの容積を $1.6 \mathrm{ml}$ としたとき，イオン 源に過負荷を与えない木知濃度試料の全压（ $\left(P_{1}\right)$ の上限 は 760 Torr であった. サンプリング可能な最小試料压 はサンプリングバルブの漏れによって決まり，本研究で 用いた六すバルブ (Valco 社) の場命，約 1 Torr であ った. サンプリングできる最小の一酸化炭素分厅も又 六オバルブの漏れにより決束り，この場命約 $4 \times 10^{-2}$ Torr であった.

面積強度測定の精度は主にピュアンメーターのノイズ レベルで決まる。用いたピュアンメーターのノイズレべ ルは $3 \times 10^{-14} \mathrm{~A}$ であるから， $\mathrm{S} / \mathrm{N}$ 比を 100 以上でイ オン電流を測定しようとすれば，検出可能なイオン電流 の最小值は約 $3 \times 10^{-12}$ A である.

GC-MS の感度が一定でなくなる二酸化炭素の分压 は，マスフィルターの透過率が一定でなくなるイオンの 量及び充てん剤に過負荷を与えない条件によって決ま る.本研究で用いた装置の場合，それぞれ約 $2 \times 10^{-9}$ A 以下のイォン電流及び約 20 Torr 以下の二酸化炭素 分王であった。

以上の結果をまとめて Fig. 5 に示す. 丸印は実測值 で傾き 1 の直線にのる. エミッション電流, 電子加速電 压等イオン化の条件を变えるとこの直線は上下に平行移 動する.この直線が破線で囲まれた領域内で最も長くと れる場合のイオン化の条件が最適のわのとなる.

Fig. 5 に示した例の場合, 直線が破線 (b) と交わっ ていることから，定量可能な濃度の下限は六方バルブの 性能によって決まり約 $55 \mathrm{ppm}$ となる.

$$
3 \text { 結論 }
$$

䆓素中の微量不純物ガスの分析を高精度で検量線法に より行うことはできない。しかし，次のよらな幾つかの 注意を払らことにより，簡単な操作で $100 \%$ から ppm 程度の二酸化炭素の濃度のわのを $2 \%$ 以下の精度で定 量分析することができる。

（1）マスフィルターの検出器としてはファラデーカ ップを用いる.

(2) リペラー電極の電位を梥素がイオン源に流入し ている間 $-9 \mathrm{~V}$ とて，大量に存在する窒素のマスフィ ルターヘの影響を除く.

(3) 前もって，GC-MS の感度が二酸化炭素分圧依 存性を示さない領域を決めておく。この領域はマスフィ 


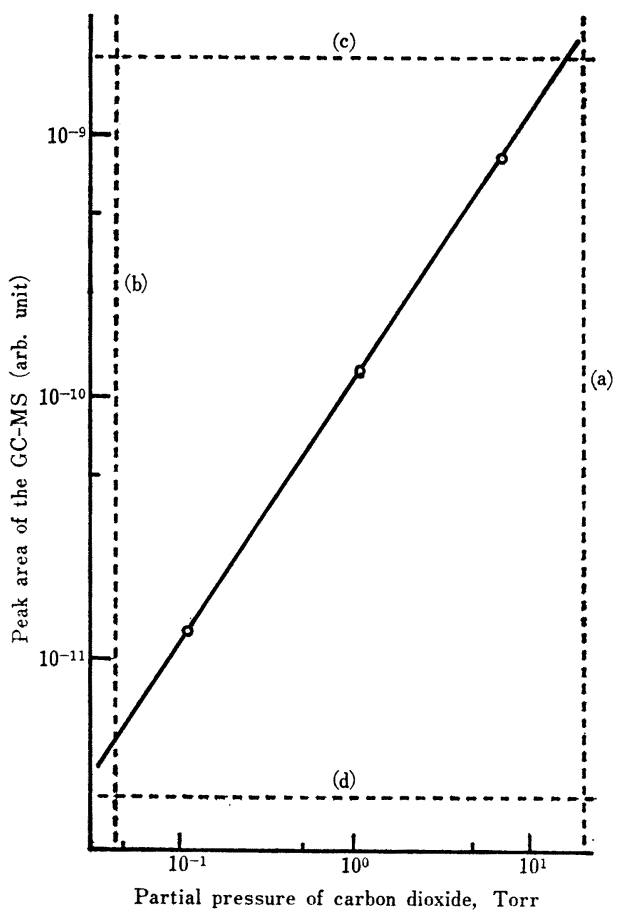

Fig. 5 The graph indicating the conditions to analyse carbon dioxide in nitrogen quantitatively with the gas chromatograph-mass spectrometer

In the region surrounded by four dotted lines (a), (b), (c), and (d), carbon dioxide in nitrogen is analysed quantitatively. The dotted line (a) indicates the limit that over this partial pressure of carbon dioxide a column of the gas chromatograph saturates. The dotted line (b) indicates the limit that under this partial pressure of carbon dioxide leak of carbon dioxide in air through the sampling valve become serious. The dotted line (c) indicates the linit that over this peak area the mass spectrometer saturates. The dotted line (d) indicates the limit that under this peak area the noise level of the picoammeter becomes serious.

ルター及び充てん剂に過負荷を与它ない二酸化炭素の分 压，サンプリングバルプの漏れ及びピュアンメーターの ノイズレペルにより決まり長期間変わらない。この領域 内で定量分析を行らよう，ガスクロマトグラフ及びマス フィルターの測定条件を定める.

（4）GG-MS の安定性を調へ，GG-MS の状態が变 化しないとみなせる時間をあらかじめ決めておく。この 時間内で連続して未知濃度試料と参照試料の測定を行 い，2.5で述べた方法により濃度を決定する.

この方法は二酸化炭素以外の他の種類の無機ガスにつ いても適用することができる。

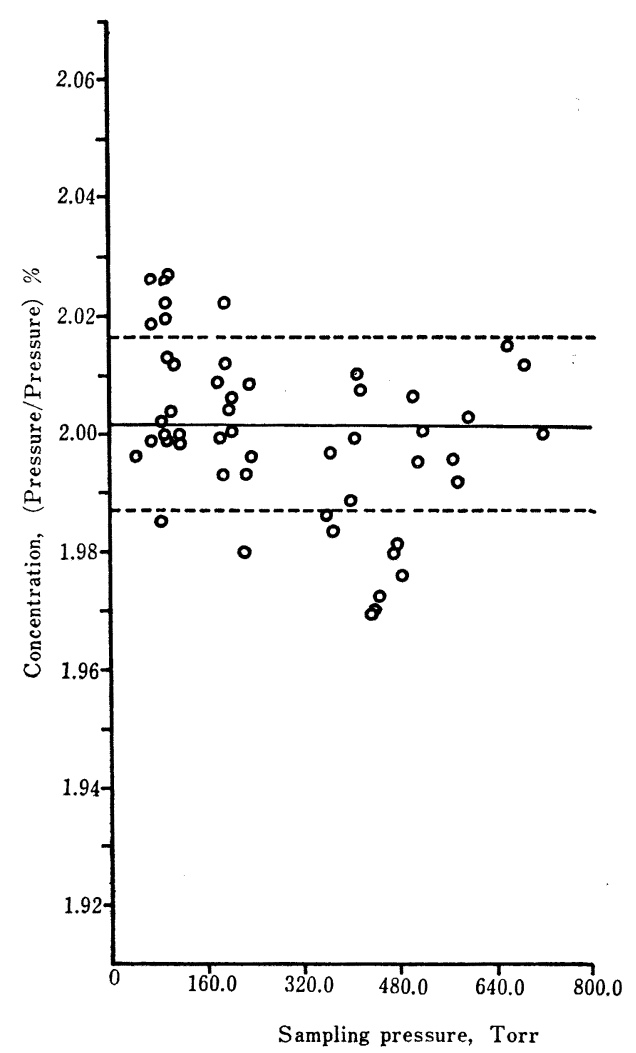

Fig. 6 Concentration determined by the present method

Number of points is 54 . Solid line indicates the mean value $(2.003 \pm 0.002 \%)$ and dotted lines indicate the standard deviation $(2 \sigma)$. These data were collected with varying sample pressures for three months and this fact indicates that the procedure determined in this report does not depend on the sampling pressure and the condition of the gas chromatograph mass spectrometer. Measuring condition-Emission current $\left(I_{\mathbf{k}}\right): 100 \mu \mathrm{A}$, electron voltage $\left(E_{\mathrm{k}}\right): 70 \mathrm{eV}$

最後に，この方法を用いて未知濃度試料中の二酸化崖 素の 分析例を，試料の全币を種々変えた場合について Fig. 6 に示与.この值は同一試料についての測定を約 3 かにわたって行ったものであるが，測定点は測定值 $(2.003 \pm 0.002 \%)$ の周りに均等にばらつき，その程度 は $2 \sigma=0.8 \%$ であった.これにより, 本研究で示した 定量分析法は長期間, 装置の状熊に依存せず, 十分な精 度で濃度決定を行えることを示している。

$\left(\begin{array}{c}1976 \text { 年 } 10 \text { 月, 第 } 12 \text { 回応用スペクトロ } \\ \text { メトリー東京討論会に打いて一登表 }\end{array}\right)$

交献

1）杉江正昭, 古賀義紀, 近藤重雄, 佐伯慎之助, 山 
崎善武：日化, 1978, 382.

2) R. H. Groth, T. B. Doyl : J. Gas Chromatogr., 6, 138 (1968) .

3) E. E. Hughes, W. D. Dorko : Anal. Chem., 40, 866 (1968) .

4) W. L. Thornsberry : Anal. Chem., 43, 452 (1971).

$$
\text { is }
$$

Quantitative analysis of carbon dioxide in nitrogen by gas chromatography-mass spectrometry. Hisakazu Nozoye*, Yoshitake YAmazAKI**, Hiroshi Tomita and Kazuo Someno* (*National Chemical Laboratory for Industry, 1-1, Higashi, Yatabe-machi, Tsukuba-gun, Ibaraki; **Chemicals Inspection and Testing Institute, 4-1-1, Higashimukojima, Sumida-ku, Tokyo)

A method was proposed to solve some difficult problems in a quantitative analysis of carbon dioxide in nitrogen by a gas chromatography-mass spectrometry. The stability of the output of a mass spectrometer was improved by measuring spectra of reference gas and sample gas within $6 \mathrm{~min}$ and comparing peak areas of the spectra. A Faraday cup was superior to a secondary electron multiplier as a detector of a mass spectrometer for a quantitative analysis. The effect of nitrogen gas to the mass spectrometer was avoided by applying negative voltage to a repeller electrode, when nitrogen gas eluted from a gas chromatograph to an ion source of a mass spectrometer. With this technique that we have established the concentration of carbon dioxide in nitrogen is analyzed quantitatively from $100 \%$ to $\mathrm{ppm}$ order with very high accuracy and precision. The minimum concentration of carbon dioxide that can be analysed by the present method depends on not only the dynamic range of the mass spectrometer but also the leakage of atmospheric carbon dioxide through a sampling valve and the noise level of the picoammeter.

(Received Jan. 7, 1980)

\section{Keywords}

Carbon dioxide

Gas chromatograph

Mass spectrometer

Nitrogen 